Л.В. Олійник, полковник, кандидат педагогічних наук, старший науковий співробітник,

НУОУ імені Івана Черняховського

\title{
КОНЦЕПТУАЛЬНІ ЗАСАДИ УПРАВЛІННЯ РОЗВИТКОМ ВІЙСЬКОВО-СПЕЦІАЛЬОӦ КОМПЕТЕНТНОСТІ МАГІСТРАНТІВ В УМОВАХ УНІВЕРСИТЕТСЬКОЇ ОСВІТИ
}

В статті визначені концептуальні засади управління розвитком військовоспеціальної компетентності магістрантів. Розглядається управління як одна із сучасних концепцій розвитку військово-спеціальної компетентності магістрантів. Представлена система засобів і принципів управління якістю навчальної діяльності, яка необхідна для ефрективного розвитку військово-спеціальної компетентності магістрантів.

Ключові слова: управління; розвиток; військово-спеціальна компетентність; принциипи; магістрант.

Постановка проблеми. У педагогічній науці сьогодні триває пошук нових ефективних шляхів удосконалення освітнього процесу в умовах університетської освіти. Метою сучасної вищої військової школи повинні стати забезпечення становлення цілісної особистості, цілеспрямований вияв i розвиток іiі здібностей, формування умінь і бажання навчатися протягом усього життя, створення умов для навчання як основи багатоступеневої військової освіти. Навчання - один із найдавніших видів людської діяльності, однак протягом усієї історії сутність цього процесу залишається незмінною, виявляючись у взаємодії викладача й слухача. Цей процес нерозривно пов’язаний з поняттям “управління”. Досягнення поставленої мети в процесі навчання, формування всебічно розвиненої особистості безпосередньо залежать від управління цим процесом. Визначений процес проходить шляхом розвитку військово-спеціальної компетентності магістранта, ефективність якого залежить від використання сучасної концепції управління в умовах університетської освіти.

Аналіз досліджень і публікацій. Концептуальні засади управління розвитком військово-спеціальної компетентності, що визначають цільові, змістовні та процесуальні характеристики військово-спеціальних дисциплін, розкриті в дослідженнях багатьох вчених - А.О. Кучерявого, Є. Ю. Литвиновського, О. В. Торічного, В. В. Ягупова та інших.

Аналіз досліджень [1-5] показує, що проблему ефективної організації освітнього процесу остаточно не розв'язано. У наш час розгляд процесу навчання в умовах університетської освіти як процесу управління є досить продуктивним, проте, як показують дослідження в цій сфері, багато теоретичних i практичних питань залишаються відкритими. Теорія управління вимагає глибокого вивчення й аналізу 3 метою визначення іii дидактичних можливостей і практичної значущості.

Метою статті $\epsilon$ визначення концептуальних засад управління розвитком військово-спеціальної компетентності магістрантів в умовах університетської освіти.

Виклад основного матеріалу. Ефективна система управління освітою має містити: чіткі цільові настанови; процеси планування (проектування); 
запровадження інноваційних інформаційно-комунікаційних технологій; всебічного кадрового, матеріально-технічного, фінансового, дидактичного, інформаційного, психологічного, санітарно-гігієнічного забезпечення; контроль; моніторинг; коригування повинно бути спрямовано на досягнення кінцевого результату - якісну підготовку військових фахівців [3, с. 73].

Управління передбачає управляючі впливи та отримання від слухачів через зворотній зв'язок інформації про стан розвитку військово-спеціальної компетентності магістранта та iï результатів. I науково-педагогічний працівник і слухач як особистості є суб'єктами діяльності, спілкування. Кожен $з$ них є суб'єктом предметної діяльності, суб'єктом самосвідомості. Таким чином, науково-педагогічний працівник - суб’єкт педагогічної діяльності, а слухач - суб'єкт навчальної діяльності. Управління розвитком військово-спеціальної компетентності магістрантів в умовах університетської освіти здійснюється за допомогою певних дій, що задаються заздалегідь (контроль - корекція). Наприклад, це робота з інструкцією, що передбачає певний порядок дій слухача. При управлінні відбувається постійний контроль за ходом процесу навчання і - за необхідності - його корекція. Прикладом визначеного управління може бути опитування слухачів науковопедагогічним працівником i негайне роз'яснення помилок у засвоєнні матеріалу. У цьому разі існує прямий і зворотний зв'язок з викладачем, який значно поліпшує якість засвоєння.

Одним із видів управління можна вважати проблемне навчання. За допомогою прямого управління (питань викладача) здійснюється перехід до співуправління, а потім і до самоуправління слухача. Педагогічна ситуація скеровує розумову діяльність на розв'язання проблеми; робота в процесі розв'язання проблеми - дуже важливий етап, іноді навіть важливіший ніж саме розв'язання. Формування особистості, що здатна творчо мислити, знаходити рішення неординарним шляхом, - це мета, яку ставить перед собою викладач при переході слухачів на рівень самоуправління. Проблемні ситуації викликають у слухачів необхідність вивчати новий теоретичний i практичний матеріал; вони створюють умови для поглибленого розуміння цілей і змісту навчання. Головним компонентом даного типу навчання $\epsilon$ особистість слухача з їі здібностями, психофізіологічними особливостями, а також індивідуальний підхід до нього. Викладач виступає організатором діяльності магістрантів і розвиває їхню мотивацію до навчання, творчу активність.

В основу концептуальних засад управління розвитком військовоспеціальної компетентності магістрантів в умовах університетської освіти покладено такі положення:

управління розвитком військово-спеціальної компетентності магістрантів в умовах університетської освіти $\epsilon$ складовою неперервної педагогічної освіти, зумовленої соціально-економічними чинниками розвитку суспільства, що враховує сучасні тенденції, вітчизняний i зарубіжний досвід підготовки магістрів, відображає специфіку магістерської підготовки (зміст, форми, методи і педагогічні технології), передбачає 
створення дієвих стимулів професійного та особистісного розвитку магістранта на основі моніторингу якості реалізації освітніх стандартів;

управління розвитком військово-спеціальної компетентності магістрантів в умовах університетської освіти розглядається як науково обгрунтована система суб'єкт-суб'єктної взаємодії, в основу побудови якої покладено принцип компетентісного підходу. Теоретичними основами побудови концепції управління розвитком військово-спеціальної компетентності магістрантів в умовах університетської освіти є сучасні освітні парадигми (антропологічна, гуманістична, гуманітарна, культурологічна), концепції (неперервна професійна педагогічна освіта, особистісно орієнтована освіта) та компетентнісний підхід;

система управління розвитком військово-спеціальної компетентності магістрантів в умовах університетської освіти має всі ознаки, властиві такій системі: слугує основою теоретичного осмислення і побудови психологопедагогічної діяльності; включає певну сукупність взаємопов'язаних засобів, методів i процесів, необхідних для створення організованого, цілеспрямованого педагогічного впливу на розвиток особистості із заданими якостями; забезпечує виконання ціннісно-змістових, нормативних, технологічних i процесуально-результативних функцій психологопедагогічної діяльності; сприяє досягненню поставлених цілей розвитку людини;

системотворчими елементами управління розвитком військовоспеціальної компетентності магістрантів в умовах університетської освіти є: загальнолюдські цінності, мета, завдання та особливості науковопедагогічної діяльності, закономірності й принципи навчання слухачів. Змінними складовими $є$ : організаційно-педагогічні умови здійснення освітнього процесу (зміст, форми, технології його організації, умови кадрового, фінансово-матеріального i науково-методичного забезпечення, методика діагностики, результативність). Управління розвитком військовоспеціальної компетентності магістрантів в умовах університетської освіти можливе за умови реалізації в освітньому процесі системи принципів, що визначають цілі й зміст навчання магістрантів, розкривають особливості удосконалення науково-педагогічної діяльності.

Аналіз передового педагогічного досвіду, експериментальні дослідження у Національному університеті оборони України імені Івана Черняховського дозволяють сформулювати правила щодо визначених принципів управління розвитком військово-спеціальної компетентності магістрантів в умовах університетської освіти.

Принцип урахування освітніх запитів і потреб особистості в межах сучасної концепції військової освіти передбачає відображення в змісті управління розвитком військово-спеціальної компетентності магістрантів в умовах університетської освіти, орієнтації на слухача як рівноправного суб'єкта педагогічного процесу, формування у нього цілісної картини світу, духовності, культури урахування при педагогічному проектуванні змісту здатності до навчання, рівня сформованості творчого мислення слухача, обов'язкове формування умінь раціональної навчальної діяльності, 
саморозвитку, творчого, інтуїтивного мислення, удосконалення комунікативних умінь, забезпечення логічно-послідовного, гармонійного розвитку особистості в процесі розвиваючого, творчого навчання, самовдосконалення.

Принцип об'єктивізації відповідно до змісту освіти щодо об'єкта діяльності та функцій, які повинні виконувати військові фахівці, $\epsilon$ забезпечення у змісті навчання слухача реального поєднання теорії i практики, наближення до реальних потреб Збройних Сил України, запровадження компетентісного підходу до навчання.

Принцип багаторівневості, спадкоємності i доступної ускладненості змісту управління розвитком військово-спеціальної компетентності магістрантів в умовах університетської освіти передбачає широту охоплення тематики підготовки та більш глибоке теоретичне опанування науковим змістом слухачами, визначення відповідно до цього навчальних модулів, тем, їх послідовності, оптимального часу на засвоєння навчального матеріалу, відповідної методики.

Цей принцип передбачає розроблення та застосування при вивченні кожної навчальної дисципліни відповідної технологічної карти, яка впорядковує послідовність переходу від одних дидактичних цілей до інших із зміною "репертуару” методичних, організаційних і технічних засобів, структурування навчального матеріалу (виділення понять, принципів, ідей, загальних зв’язків між цими елементами), що дозволяє слухачу засвоювати не тільки елементи знань, а й зв'язки між ними.

Принцип взаємозумовленості складових і компонентів змісту управління розвитком військово-спеціальної компетентності магістрантів в умовах університетської освіти передбачає наукове обгрунтування ефективності функціонування педагогічної системи підготовки визначених фахівців та іï основних елементів: мети, змісту, методів, засобів, форм викладання та навчання, врахування міждисциплінарного контексту, чіткого визначення місця, ролі та функцій змісту конкретної навчальної дисципліни у загальній системі підготовки фахівця, розкриття у змісті програми завдань: освітніх, виховних, психологічної підготовки, розвитку творчого мислення у слухачів, конкретність і процесуальність, репрезентованість модульної побудови змісту навчального матеріалу.

Принцип конструктивного заняття - збереження попереднього позитивного досвіду щодо змісту навчання, його переосмислення й інтегрування в нове ціле на сучасних світоглядних та методологічних засадах вимагає побудови змісту, який забезпечує системність та наступність у навчанні, запровадження нового і прогресивного, формування відповідно до цього оптимальної мотиваційної основи дій у викладачів та слухачів, оптимізацію обсягу та інтенсивності навчальної діяльності, раціональне поєднання фронтальної, групової та індивідуальної пізнавальної активності слухачів, ̈̈х самостійної творчої роботи, дотримання критерію різноманітності щодо форм проведення занять при складанні тематичних планів, що буде сприяти збереженню та розвитку інтересу, активності слухачів і відповідати оптимальній логіці пізнання специфічного змісту. 
В основу управління розвитком військово-спеціальної компетентності магістрантів в умовах університетської освіти покладений принцип зворотного зв'язку. Саме завдяки зворотному зв'язку забезпечується динаміка освітнього процесу та реалізується мета навчання. За допомогою зворотного зв'язку науково-педагогічний працівник коригує процес навчання, має можливість враховувати необхідні зміни в педагогічній системі і вчасно коригувати хід процесу.

Визначені принципи враховуються при визначенні методів, форм i засобів та стійкої мотивації навчальної діяльності магістрантів, розглядається відповідно до вимог модернізації освітнього процесу, тому цій системі надається насамперед практичного спрямування, що має забезпечити ефективність духовного і фізичного розвитку особистості, вироблення умінь і навичок самоосвіти, реалізації ii індивідуальних здібностей та творчого потенціалу.

Чим же відрізняється компетентісний підхід до управління розвитком військово-спеціальної компетентності магістрантів в умовах університетської освіти від традиційного підходу? Приведемо порівняльну характеристику (табл.).

3 таблиці видно, що при традиційному підході програма навчання визначається відповідно до засвоєння знань, навичок, вмінь, вона уніфікована, усереднена. Управління розвитком військово-спеціальної компетентності направлено на використання слухачами власного творчого потенціалу, здатність демонструвати неповторний індивідуальний спосіб дій в різних навчальних та практичних ситуаціях.

Традиційний підхід до управління розвитком військово-спеціальної компетентності не ставить як основне завдання розвиток рефлексивних здібностей слухачів. Однак без здібностей до рефлексії принципово неможлива робота з виділення особистого досвіду навчальної діяльності та поведінки. При компетентісному підході - це обов'язкові умови для здійснення слухачами рефлексивного аналізу, прояву особистісного досвіду.

Таблиия

\section{Порівняльна характеристика традиційного і компетентісного підходів до управління розвитком військово-спеціальної компетентності магістрантів в умовах університетської освіти}

\begin{tabular}{|c|c|}
\hline Традиційний підхід & Компетентісний підхід \\
\hline \multicolumn{2}{|r|}{ Мотиваційно-цільовий компонент } \\
\hline $\begin{array}{l}\text { Визначаються цілі згідно } \\
\text { установкам програми і } \\
\text { вимогам до управління } \\
\text { розвитком } \\
\text { спеціальної компетентності } \\
\text { магістрантів в умовах } \\
\text { університетської освіти. } \\
\text { Як правило, відсутній } \\
\text { мотив і час для } \\
\text { співвідношення } \\
\text { підходів з психологічними } \\
\text { особливостями }\end{array}$ & $\begin{array}{l}\text { Визначається таксономія цілей, класифікація їх на системні, } \\
\text { предметні, модульні і цілі конкретного заняття, які чітко та } \\
\text { діагностично визначені, що дає можливість описати результат } \\
\text { розвиненості військово-спеціальної компетентності, оцінити } \\
\text { якість навчання слухача і при необхідності корегувати освітній } \\
\text { процес; при цьому враховується можливість надання слухачу } \\
\text { напрацювати власну траєкторію навчальної діяльності. } \\
\text { Мотиваційне забезпечення діяльності науково-педагогічного } \\
\text { працівника, і слухача грунтується на реалізації ї особистісних } \\
\text { функцій в цьому процесі (вільний вибір, креативність, } \\
\text { змагальність, життєвий і професійний сенс). }\end{array}$ \\
\hline
\end{tabular}




\begin{tabular}{|c|c|}
\hline \multicolumn{2}{|r|}{ Змістовний компонент } \\
\hline $\begin{array}{l}\text { Головна відмінність - } \\
\text { уніфікація, обов'язковість } \\
\text { для всіх, деяка } \\
\text { посередність }\end{array}$ & $\begin{array}{l}\text { Стандарт освіти збагачується за рахунок диференціації слухача } \\
\text { за рівнем підготовленості, поглиблюється програма професійної } \\
\text { підготовки при цьому визначаються: необхідні навчальні } \\
\text { елементи розвитку військово-спеціальної компетентності } \\
\text { (модулі, розділи), які виявляють системоутворюючі зв'язки, } \\
\text { ефективність функціонування навчально-виховної системи в } \\
\text { цілому для досягнення цілей управління розвитком військово- } \\
\text { спеціальної компетентності магістрантів в умовах } \\
\text { університетської освіти; допустиме дозування визначеного } \\
\text { навчання на основі виміру інформаційної ємкості розвитку } \\
\text { військово-спеціальної компетентності слухачів до виконання } \\
\text { професійних обов'язків, яка виключає перевантаження слухачів } \\
\text { на етапах навчання. }\end{array}$ \\
\hline \multicolumn{2}{|r|}{ Операційно-діяльнісниий компонент } \\
\hline 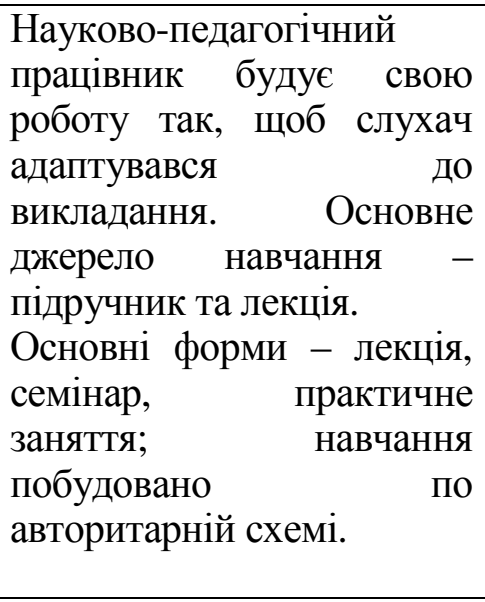 & $\begin{array}{l}\text { Виявлена і обгрунтована науково-педагогічним працівником, } \\
\text { логіка організації педагогічної взаємодії з слухачами на рівні } \\
\text { суб'єкт-суб'єктних відношень - визначені способи взаємодії } \\
\text { учасників освітнього процесу на кожному етапі навчання, яка } \\
\text { відрізняється високим рівнем взаєморозуміння, низьким рівнем } \\
\text { зайвої інформації, економією часу ії передачі. Характерна } \\
\text { варіативність навчання, яка забезпечує управління пізнавальною } \\
\text { діяльністю слухачів: проблемні питання, ситуації, дискусії, } \\
\text { ділові ігри, тренінги, захист проектів та ін., при цьому } \\
\text { сполучення форм залежить від мети і змісту навчання. } \\
\text { Оптимальне співвідношення організаційних форм, методів, } \\
\text { засобів індивідуальної і групової діяльності забезпечує } \\
\text { поетапний розвиток необхідних знань навичок і вмінь. }\end{array}$ \\
\hline \multicolumn{2}{|r|}{ Діагностичний компонент } \\
\hline $\begin{array}{l}\text { Використовується } \\
\text { традиційна п’ятибальна } \\
\text { оцінка знань, аналіз якості } \\
\text { освіти по підсумках } \\
\text { іспитів і заліків. }\end{array}$ & $\begin{array}{l}\text { Визначені процедури контролю і виміру якості розвиненості } \\
\text { військово-спеціальної компетентності. По результатам } \\
\text { контролю науково-педагогічними працівниками уточнюється } \\
\text { мета і зміст навчання, переглядаються підходи до вибору } \\
\text { організаційних форм і методів чи перебудовується зміст } \\
\text { навчання. }\end{array}$ \\
\hline
\end{tabular}

Принциповою відмінністю навчання у військовому університеті $\epsilon$ те, що воно спрямоване на оволодіння слухачами навичок виконання своїх функціональних обов'язків за посадовим призначенням тобто компетенцій.

Управління розвитком військово-спеціальної компетентності магістрантів в умовах університетської освіти досягається шляхом: формування мети навчання; розробки програми дій, що передбачає основні перехідні стани процесу навчання; отримання даних по певним параметрам про стан процесу навчання (зворотній зв'язок); переробки інформації, отриманої по каналу зворотного зв'язку, відпрацювання i внесення в управління розвитком військово-спеціальної компетентності магістрантів.

На підставі аналізу психолого-педагогічної літератури можна дійти висновку, що основною особливістю сучасної вищої освіти стає ії гуманістична спрямованість, коли головна увага має приділятися формуванню всебічно розвинутої особистості. Розгляд процесу навчання як процесу управління розвитком військово-спеціальної компетентності магістрантів дає змогу ефективніше ставити завдання навчання, проектувати 
процес навчання і необхідні засоби, здійснювати постійну взаємодію науково-педагогічного працівника і слухача завдяки наявності зворотного зв'язку, коригувати хід процесу навчання 3 метою його оптимізації. Управління розвитком військово-спеціальної компетентності магістрантів в умовах університетської освіти - це така форма організації освітнього процесу педагогом, яка націлена на конкретний результат - оволодіння слухачем професійними знаннями, уміннями та навичками; ефективність даного процесу забезпечується зворотним зв'язком на всіх етапах розвитку військово-спеціальної компетентності. Ефективність управління розвитком військово-спеціальної компетентності магістрантів в умовах університетської освіти безпосередньо залежить від засобів, застосовуваних в освітньому процесі; отже, дидактичні засоби можуть розглядатись як засоби управління розвитком військово-спеціальної компетентності. Функції управлінської діяльності (проектування, організація, керівництво, контроль і корекція) мають загальний характер і повинні застосовуватися до процесу навчання 3 метою підвищення розвиненості військово-спеціальної компетентності магістрантів.

Отже, управління розвитком військово-спеціальної компетентності магістрантів в умовах університетської освіти є ефективним за умов, коли:

вихідні методологічні засади дослідження спираються на компетентісний підхід.

зміст i структура управління розвитком військово-спеціальної компетентності магістрантів в умовах університетської освіти обумовлюються концептуально-теоретичною моделлю, сутнісними складовими i системоутворювальними чинниками якої виступають професіоналізм педагогічної діяльності (продуктивність і майстерність) та професіоналізм особистості слухача (здатність до педагогічної творчості);

основою управління розвитком військово-спеціальної компетентності магістрантів в умовах університетської освіти виступає методична система в єдності ऑii мотиваційно-цільових, змістових, операційно-процесуальних i результативних компонентів, що поетапно реалізується в освітньому процесі 3 врахуванням визначеного комплексу базових підходів, напрямів, організаційних педагогічних умов. Напрямками подальшого дослідження $\epsilon$ визначення основ побудови методичної системи управління розвитком військово-спеціальної компетентності магістрантів в умовах університетської освіти.

\section{ЛІТЕРАТУРА}

1. Кучерявий A.O. Управління самостійною навчальною діяльністю майбутніх юристів: монографія / А. О. Кучерявий. - Черкаси : видавець Чабаненко Ю.А., 2014. - 344 с.

2. Литвиновський $Є$.Ю. Формування в офіцерів структури виховної роботи Збройних Сил України вмінь проектування виховного процесу: дис. ... канд. пед. наук : 13.00.04 / Литвиновський Євгеній Юрійович. - К, 2003. - 208 с.

3. Олійник Л. В. Якість підготовки військових фахівців як результат ефективної системи управління освітою/ Л.В. Олійник, О.А. Прохоров Збірник наукових праць 
"Військова освіта" Національного університету оборони України імені Івана Черняховського. - № 2 (32). - 2015. - С. 164-173.

4. Торічний O.B. Теоретико-методичні засади формування військово-спеціальної компетентності майбутніх офіцерів-прикордонників у процесі навчання : автореф. дис. на здобуття наук. ступеня доктора пед. наук : спец. 13.00.02 “Теорія та методика навчання (загальновійськові й військово-спеціальні дисципліни)” / О. В. Торічний. - К., 2013. - 38 с.

5. Ягупов B.B Загальнодидактичні основи навчання військовослужбовців строкової служби Збройних Сил України : автореф. дис. на здобуття наук. ступеня доктора пед. наук : спец. 13.00.04 “Теорія та методика професійної освіти” / В. В. Ягупов - К., 2002. $26 \mathrm{c}$.

Л.В. Олейник, кандидат педагогических наук, старший научный сотрудник,

НУОУ имени Ивана Черняховского

\section{КОНЦЕПТУАЛЬНЫЕ ОСНОВЫ УПРАВЛЕНИЯ РАЗВИТИЕМ ВОЕННО- СПЕЦИАЛЬНОЙ КОМПЕТЕНТНОСТЬЮ МАГИСТРАНТОВ В УСЛОВИЯХ УНИВЕРСИТЕТСКОГО ОБРАЗОВАНИЯ}

В статье определены концептуальные основы управления развитием военноспециальной компетентностью магистрантов в условиях университетского образования. Рассматривается управления как одна из конщепщий развития военно-специальной компетентности магистрантов. Представлена система средств и принципов управления развитием военно-специальной компетентностью магистрантов в условиях университетского образования как необходимая для эффективного развития военноспецииальной компетентности.

Ключевые слова: управления; развитие; военно-спечиальная компетентность; принциньг; магистрантыл.

L. Oliynyk, candidate of pedagogical sciences,

senior researcher, NDUU named after I. Cherniahovsky

CONCEPTUAL BASES DEVELOPMENT SPECIAL MILITARY COMPETENCE CONTROL MANAGEMENT MASTERS IN CONDITION UNIVERSITY EDUCATION

The article reveals conceptual bases of management masters of the development special military competence control. Development special military competence control is considered as one of the modern conceptions of special military competence development of management masters. System of means and principles of the development special military competence control as necessary one for effective special military competence development management masters.

Key words: control; development special military competence; special military competence; principles; management masters. 